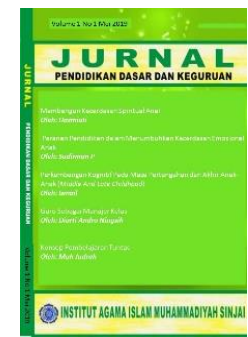

JURNAL

Pendidikan Dasar dan Keguruan

Volume 6, No. 1, 2021

ISSN (print) : 2527-578X

ISSN (Online): 2715-6818

Homepage : http://journal.iaimsinjai.ac.id/index.php/JPDK

\title{
PENGARUH KEPEMIMPINAN KEPALA SEKOLAH TERHADAP KINERJA GURU DI SDN 45 LEMPANGAN SINJAI SELATAN
}

\author{
Warni $^{1}$, R. Nurhayati ${ }^{2}$, Muh. Judrah ${ }^{3}$, Syarifuddin ${ }^{4}$ \\ ${ }^{1}$ IAI Muhammadiyah Sinjai \\ ${ }^{2}$ IAI Muhammadiyah Sinjai \\ ${ }^{3}$ IAI Muhammadiyah Sinjai \\ ${ }^{4}$ IAI Muhammadiyah Sinjai \\ warnidompala@gmail.com, rnurhayati1984@gmail.com,muh.judrah68@gmail.com, \\ hidayatullahsyarif05@gmail.com
}

\begin{abstract}
Abstrak
Penelitian ini bertujuan untuk membuktikan pengaruh kepemimpinan kepala sekolah terhadap kinerja guru di SDN 45 Lempangan Sinjai Selatan dan untuk mengetahui besar pengaruh kepemimpinan kepala sekolah terhadap kinerja guru di SDN 45 Lempangan Sinjai Selatan. Penelitian ini merupakan penelitian Expost facto dengan menggunakan pendekatan kuantitatif, dengan jumlah populasi 8 orang dan adapun yang menjadi sampel penelitian ini sebanyak 8 orang. Data yang diambil dengan menggunakan angket dan dokumen. Pengolahan data memakai teknik analisis regresi linear sederhana dengan taraf signifikan $95 \%$ dengan menggunakan SPSS 25. Penelitian ini menunjukkan bahwa Kepemimpinan Kepala Sekolah memiliki pengaruh positif dan signifikan terhadap kinerja guru di SDN 45 Lempangan Sinjai Selatan. Hal ini diperoleh berdasarkan hasil analisis dengan menggunakan SPSS 25, Pada tabel coefficients diketahui thitung kepemimpinan kepala sekolah 4,435 > dari tabel 2,477 dan nilai probablitas 0,004 < 0,05 dan pada tabel model summary dengan melihat $R$ Square =0,766 atau 76,6 \%. Jadi besar pengaruh kepemimpinan kepala sekolah terhadap kinerja guru di SDN 45 Lempangan Sinjai Selatan adalah 76,6\%.
\end{abstract}

Kata Kunci: Kepemimpinan Kepala Sekolah, Kinerja Guru

\begin{abstract}
This study aims to prove the influence of the Principal's Leadership on Teacher Performance at SDN 45 Lempangan Sinjai Selatan. and to find out the influence of the Principal's Leadership on Teacher Performance at SDN 45 Lempangan Sinjai Selatan. This research is an Expost facto research using a quantitative approach with a population of 8 people and as for the sample of this study as many as 8 people. Data taken using questionnaires and documents. Data processing using simple linear regression analysis techniques with a significant level of 95\%. This study shows that: Principal leadership has a positive and significant influence on teacher performance at SDN 45 Lempangan Sinjai Selatan. This is obtained based on the results of the analysis using SPSS 25, in the coefficients table it is known that the t-count $o$ the headmaster's is 4,435 > from the t-table 2,477 and the probability value is $0,004<0,05$ and in the model summary table by seeing $R$ square $=0,766$ or 76,6\%. So the influence o the principal's leadership on the performance of the teachers at SDN 45 Lempangan Sinjai Selatan is 76,6\%.
\end{abstract}




\section{Pendahuluan}

Pendidikan adalah usaha sadar yang dilakukan orang dewasa (pendidik) dalam menyelenggarakan kegiatan pengembangan diri peserta didik agar menjadi manusia yang paripurna sesuai dengan tujuan yang telah ditentukan sebelumnya. Pendidikan bisa membantu manusia mengangkat harkat dan martabatnya dibandingkan manusia lainnya yang tidak berpendidikan. Pendidikan adalah bimbingan atau pimpinan secara sadar oleh pendidik terhadap perkembangan jasmani dan rohani anak didik menuju terbentuknya kepribadian utama menurut ukuran-ukuran tertentu.

Pendidikan dalam pelaksanaannya selama ini dikenal sebagai usaha yang berbentuk bimbingan terhadap anak didik guna mengantarkan anak kearah pencapaian cita-cita tertentu dan proses perubahan tingkah laku ke arah yang lebih baik. Di antara solusi yang perlu diperhitungkan dan diupayakan dalam membentuk kepribadian dan perubahan tingkah laku ialah melalui pendidikan agama baik secara formal di sekolah maupun secara non formal. Kompri, (2016:15).

Guru adalah salah satu komponen manusiawi dalam proses pembelajaran, yang ikut berperan dalam usaha pembentukan sumber daya manusia yang potensial di bidang pembangunan. Oleh karena itu guru yang merupakan salah satu unsur dibidang kependidikan harus berperan secara aktif dan menempatkan kedudukannya sebagai tenaga profesional sesuai dengan tuntutan masyarakat yang semakin berkembang. Dalam hal ini guru tidak semata-mata sebagai pengajar yang melakukan transfer ilmu pengetahuan, tetapi juga sebagai pendidik yang melakukan transfer nilai-nilai sekaligus sebagai pembimbing yang memberikan pengarahan dan menuntun siswa dalam belajar. Barnawi dan Mohammad Arifin, (2012:11).

Kelengkapan dari jumlah tenaga pengajar dan kualitas dari guru tersebut akan mempengaruhi keberhasilan siswa dalam belajar yang berujung pada peningkatan mutu pendidikan. Untuk itu guru dituntut lebih profesional dalam menjalankan tugasnya.

Tugas Keprofesionalan Guru menurut Undang-Undang Republik Indonesia Nomor 14 Tahun 2005 pasal 20 (a) Tentang Guru dan Dosen adalah merencanakan pembelajaran, melaksanakan proses pembelajaran yang bermutu serta menilai dan mengevaluasi hasil pembelajaran. (UU RI Nomor 14 Tahun 2005 tentang Guru dan Dosen, 2006:24). Tugas pokok guru tersebut yang diwujudkan dalam kegiatan belajar mengajar serta tugas-tugas guru dalam kelembagaan merupakan bentuk kinerja guru. Apabila kinerja guru meningkat maka berpengaruh pada peningkatan kualitas keluaran atau outputnya. Oleh karena itu perlu dukungan dari berbagai pihak sekolah untuk meningkatkan kinerja guru.

Keberhasilan pendidikan di sekolah sangat ditentukan oleh keberhasilan kepala sekolah dalam mengelola tenaga kependidikan yang tersedia di sekolah. Kepala sekolah merupakan salah satu komponen pendidikan yang berpengaruh dalam meningkatkan kinerja guru. Kepala sekolah bertanggung jawab atas penyelenggaraan kegiatan pendidikan, administrasi sekolah, pembinaan tenaga kependidikan lainnya dan pendayagunaan serta pemeliharaan sarana dan prasarana. Hal tersebut menjadi lebih penting sejalan dengan semakin kompleksnya tuntutan tugas kepala sekolah yang menghendaki dukungan kinerja yang semakin efektif dan efisien. Di samping itu, perkembangan ilmu pengetahuan dan teknologi serta seni dan budaya yang diterapkan dalam pendidikan di sekolah juga cenderung bergerak semakin maju sehingga menuntut penguasaan secara profesional. Menyadari hal tersebut setiap kepala sekolah dihadapkan pada tantangan untuk melaksanakan pengembangan pendidikan secara terarah, berencana dan berkesinambungan. Kepala sekolah sebagai pimpinan tertinggi yang sangat berpengaruh dan menentukan kemajuan sekolah harus memiliki kemampuan administrasi memiliki komitmen tinggi dan luwes dalam melaksanakan tugasnya. Kepemimpinan kepala sekolah yang baik harus dapat mengupayakan peningkatan kinerja guru melalui program pembinaan kemampuan tenaga kependidikan. Oleh karena itu kepala sekolah harus mempunyai kepribadian atau sifat-sifat dan kemampuan serta keterampilan- keterampilan untuk memimpin sebuah lembaga pendidikan. Dalam perannya sebagai seorang pemimpin kepala sekolah harus dapat 
memperhatikan kebutuhan dan perasaan orang-orang yang bekerja sehingga kinerja guru selalu terjaga.

Dalam pelaksanaan tugas mendidik, guru memiliki sifat dan perilaku yang berbeda, ada yang bersemangat dan penuh tanggung jawab dan ada juga guru yang dalam melakukan pekerjaan itu tanpa dilandasi rasa tanggung jawab, selain itu juga ada guru yang sering membolos, datang tidak tepat pada waktunya dan tidak mematuhi perintah. Kondisi guru seperti itulah yang menjadi permasalahan di setiap lembaga pendidikan formal. Dengan adanya guru yang mempunyai kinerja rendah sekolah akan sulit untuk mencapai hasil seperti yang diharapkan.

Berdasarkan hasil observasi dengan Kepala Sekolah SDN 45 Lempangan Sinjai Selatan yang beralamatkan Desa Puncak, Dusun Sapaere Sinjai Selatan. Kinerja Guru berupa melakukan perencanaan, pelaksanaan serta evaluasi pembelajaran yang dikemas dalam mengelola kegiatan belajar mengajar di SDN 45 Lempangan Sinjai Selatan sudah cukup baik dalam menjalankan tugasnya. Dalam observasi ini kepala sekolah menginformasikan bahwa bahwa secara umum kinerja guru-guru dilingkungan sekolahnya sudah cukup baik dalam menjalankan tugasnya. (Hasil Wawancara) Ada banyak faktor yang mempengaruhi kinerja dari seorang guru salah satunya adalah kepemimpinan kepala sekolah. Berdasarkan hasil observasi dengan beberapa guru, kepemimpinan kepala sekolah mempengaruhi kinerja mereka tetapi tak hanya itu ada aktor lain selain kepemimpinan kepala sekolah, seperti lingkungan sekolah, orang tua peserta didik, dan kondisi peserta didik. Terkait dengan uraian di atas, maka dari itu peneliti tertarik melakukan penelitian dengan judul "Pengaruh Kepemimpinan Kepala Sekolah Terhadap Kinerja Guru Di SDN 45 Lempangan Sinjai Selatan”

\section{Metode}

\subsection{Populasi dan Sampel}

Populasi adalah keseluruhan dari obyek yang akan diteliti dimana hasil dari penelitian ini berlaku. Maka yang menjadi populasi adalah seluruh guru tetap di SDN 45 Lempangan Sinjai Selatan.

\begin{tabular}{ccc} 
& \multicolumn{2}{c}{ Tabel 1. Guru Tetap di SDN 45 Lempangan Sinjai Selatan } \\
\hline NO & URAIAN & Jumlah \\
\hline 1 & Kepala Sekolah & 1 \\
\hline 2 & Guru Tetap & 8 \\
\hline & Jumlah & 9
\end{tabular}

Sumber Data: Tata Usaha SDN 45 Lempangan Sinjai Selatan

\subsection{Sampel}

Sampel adalah bagian dari jumlah dan karakteristik yang dimiliki oleh populasi tersebut. Bila populasi besar, dan peneliti tidak mungkin mempelajari semua yang ada pada populasi, misalnya karena keterbatasan dana, tenaga dan waktu, maka peneliti dapat menggunakan sampel yang diambil dari populasi itu. Untuk itu sampel yang diambil dari populasi harus betul-betul representatif (mewakili). Sugiono, (2011: 118) Untuk menentukan sampel yang akan digunakan dalam penelitian ini, maka peneliti menggunakan total sampling untuk menentukannya. Total sampling yaitu keseluruhan populasi yang menjadi sampel yang berjumlah 9 orang pendidik.

\subsection{Teknik Pengumpulan Data}

Teknik pengumpulan data adalah cara-cara yang digunakan oleh peneliti untuk mengumpulkan data. Teknik pengumpulan data adalah alat bantu yang dipilih dan digunakan oleh peneliti dalam kegiatannya agar kegiatan tersebut menjadi sistematis dan dipermudah olehnya. Karena penelitian ini bersifat kuantitatif, maka teknik pengumpulan data yang digunakan oleh peneliti adalah:

a. Metode Kuesioner (angket)

Metode Kuesioner (angket) merupakan teknik pengumpulan data yang dilakukan dengan cara memberi seperangkat pertanyaan atau pernyataan tertulis kepada responden untuk dijawabnya. Kuesioner merupakan teknik pengumpulan data yang efisien bila peneliti tahu pasti variabel yang akan diukur dan tahu apa yang bisa diharapkan dari responden. Selain itu 
juga kuesioner juga cocok digunakan bila jumlah responden cukup besar dan tersebar di wilayah yang luas. Kuesioner dapat berupa pertanyaan/pernyataan tertutup atau terbuka, dapat diberikan kepada responden secara langsung atau dikirim melalui pos, atau internet. Kuesiner dalam penelitian ini masing-masing adalah pertanyaan tentang kepempiminan Kepala Sekolah dan Kinerja Guru. penggunaan kuesioner untuk mendapatkan data yang berkaitan dengan Pengaruh Kepemimpinan Kepala Sekolah Terhadap Kinerja Guru di SDN 45 Lempangan Sinjai Selatan.

b. Metode Dokumen

Dokumen berasal dari barang-barang tertulis pada dasarnya merupakan segala bentuk sumber informasi yang berhubungan dengan penelitian baik dokumen resmi maupun tidak resmi. Dokumentasi yaitu mencari data dengan hal-hal atau variabel yang berupa catatan, transkrip, buku, surat kabar, majalah, prasasti, notulen rapat, agenda, dan sebagainya. Dengan metode dokumentasi yang diamati bukan benda hidup tetapi benda mati. Metode ini digunakan peneliti untuk mendapatkan data yang berkaitan dengan Guru Tetap di SDN 45 Lempangan Sinjai Selatan. Dokumen yang diamati dalam penelitian ini berupa perangkat pembelajaran, daftar hadir, rencana pelaksanaan pembelajaran dan lembar penilian siswa.

\subsubsection{Teknik Analisis Data}

Dalam penelitian kuantitatif, analisis data merupakan kegiatan setalah data dari seluruh responden atau sumber data lain terkumpul. Teknik analisis data dalam penelitian kuantitatif menggunakan statistik. Sugiono, (2011:207) Dalam penelitian ini penulis menggunakan analisis data yang digunakan uji regresi linear sederhana dengan menggunakan bantuan aplikasi SPSS 25.

\section{Hasil dan Pembahasan}

\subsection{Deskripsi Responden}

Responden dalam penelitian ini adalah seluruh guru yang ada di sekolah. Adapun populasinya berjumlah 8 orang pendidik dan merupakan sebagai sampel. Dalam memberikan informasi tentunya peneliti harus mengetahui atau mengenali identitas diri dari responden. Untuk lebih jelasnya akan diuraikan sebagai berikut:

Tabel 2. Data deskripsi responden

\begin{tabular}{ccccccc}
\hline No & $\begin{array}{c}\text { Kode Responden } \\
\text { (Inisial) }\end{array}$ & JK & Umur & Gol & $\begin{array}{c}\text { Pend. } \\
\text { Akhir }\end{array}$ & Mengajar \\
\hline 1 & BNG & P & 42 tahun & II c & S.1 & Kelas V \\
\hline 2 & MRD & P & 29 tahun & - & S.1 & Kelas IV \\
\hline 3 & KRT & P & 59 tahun & IV a & S.1 & Kelas III \\
\hline 4 & NHY & P & 29 tahun & - & S.1 & PAI \\
\hline 5 & MRY & P & 51 tahun & IV a & S.1 & Kelas I \\
\hline 6 & NRY & P & 56 tahun & IV a & S.1 & Kelas VI \\
\hline 7 & BRH & L & 33 tahun & III d & S.1 & PJOK \\
\hline 8 & SHR & P & 33 tahun & - & S.1 & Kelas II \\
\hline
\end{tabular}

Sumber Data: Biodata responden

\subsection{Analisis Hasil Penelitian}

Untuk mengetahui pengaruh pengaruh kepemimpinan kepala sekolah terhadap kinerja guru di

SDN 45 Lempangan, penulis menggunakan teknik pengumpulan data yaitu angket dan dokumen, dimana sampelnya 8 orang pendidik yang terdiri dari 14 Item pertanyaan dalam angket, 7 item pertanyaan untuk variabel X (kepemimpinan kepala sekolah), dan 7 item pertanyaan untuk variabel Y (kinerja guru). Adapun hasil analisis yaitu sebagai berikut: 


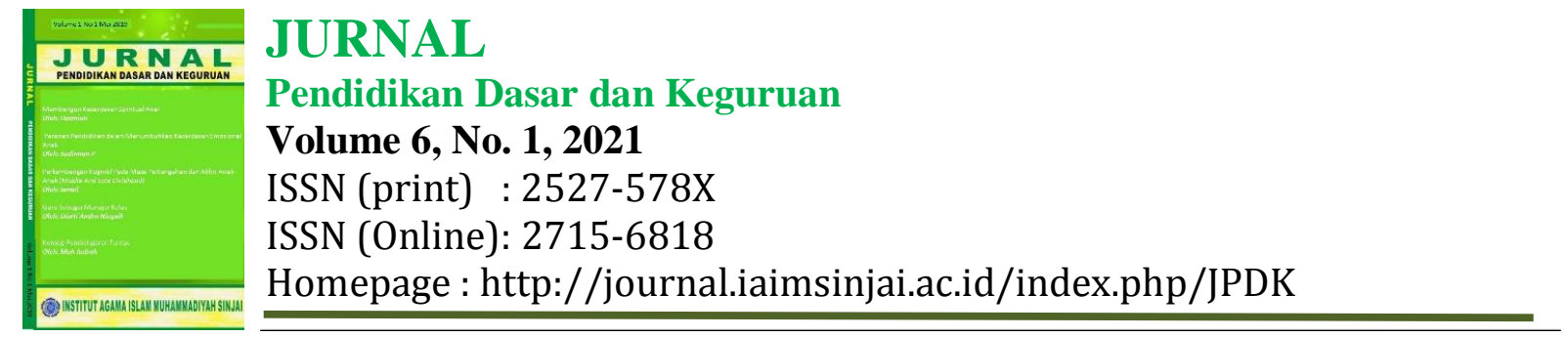

a. Uji Normalitas

Tabel 3

\begin{tabular}{|c|c|c|c|}
\hline \multicolumn{4}{|c|}{ One-Sample Kolmogorov-Smirnov Test } \\
\hline & & Kepemimpinan Kepala Sekolah & Kinerja Guru \\
\hline \multicolumn{2}{|l|}{$\mathrm{N}$} & 8 & 8 \\
\hline \multirow{2}{*}{$\begin{array}{l}\text { Normal } \\
\text { Parameters }{ }^{\mathrm{a}, \mathrm{b}}\end{array}$} & Mean & 31,38 & 30,00 \\
\hline & $\begin{array}{l}\text { Std. } \\
\text { Deviation }\end{array}$ & 2,504 & 2,673 \\
\hline \multirow{3}{*}{$\begin{array}{l}\text { Most Extreme } \\
\text { Differences }\end{array}$} & Absolute & 224 & 244 \\
\hline & Positive & ,204 & , 148 \\
\hline & Negative &,- 224 &,- 244 \\
\hline \multicolumn{2}{|l|}{ Test Statistic } & ,224 & ,244 \\
\hline \multicolumn{2}{|l|}{ Asymp. Sig. (2-tailed) } & $200^{\mathrm{c}, \mathrm{d}}$ & $176^{\mathrm{c}}$ \\
\hline \multicolumn{4}{|c|}{ a. Test distribution is Normal. } \\
\hline \multicolumn{4}{|c|}{ b. Calculated from data. } \\
\hline \multicolumn{4}{|c|}{ c. Lilliefors Significance Correction. } \\
\hline \multicolumn{4}{|c|}{ d. This is a lower bound of the true significance. } \\
\hline
\end{tabular}

Sumber Data: Hasil Output SPSS 25

Kaidah pengambilan keputusan dalam uji normalitas K-S, yaitu:

a. Jika nilai signifikansi (Sig) lebih besar dari 0,05 maka data penelitian distribusi normal.

b. Sebaiknya, jika nilai signifikansi (Sig) lebih kecil dari 0,05 maka data penelitian tidak berdistribusi normal.

Dari tabel di atas dapat diketahui, yaitu:

a. Nilai Sig Kepemimpinan Kepala Sekolah $=0,200>$ dari 0,05, maka data penelitian berdistribusi normal.

b. Nilai Sig Kinerja Guru $=0,176>$ dari 0,05, maka data penelitian berditribusi normal.

b. Deskripsi Statistik

Tabel 4

\begin{tabular}{|c|c|c|c|c|}
\hline \multicolumn{5}{|c|}{ Descriptive Statistics } \\
\hline & & Mean & Std. Deviation & $\mathrm{N}$ \\
\hline Kinerja Guru & & 30,00 & 2,673 & 8 \\
\hline $\begin{array}{l}\text { Kepemimpinan } \\
\text { Sekolah }\end{array}$ & Kepala & 31,38 & 2,504 & 8 \\
\hline
\end{tabular}

Sumber Data: Hasil Output SPSS 25

Hasil output SPSS 25 tentang Pengaruh Kepemimpinan Kepala Sekolah Terhadap Kinerja Guru Di SDN 45 Lempangan Sinjai Selatan, dari jumlah responden sebanyak 8 orang pendidik (Responden), maka dapat diketahui gambaran descriptive data masing-masing variabel yaitu nilai rata-rata (Mean) variabel kepemimpinan kepala sekolah 31,38 dengan standar devition 2,504 dan variabel kinerja guru 30,00 dengan standar deviation 2,673. 


\begin{tabular}{|l}
\hline JURNALL \\
\hline PURNAL \\
Pendidikan Dasar dan Keguruan \\
Volume 6, No. 1, 2021 \\
ISSN (print) : 2527-578X \\
ISSN (Online): 2715-6818 \\
Homepage : http://journal.iaimsinjai.ac.id/index.php/JPDK \\
\hline
\end{tabular}

c. Uji Regresi

Tabel 5

\begin{tabular}{|c|c|c|c|c|c|}
\hline \multicolumn{6}{|c|}{ Coefficients $^{\mathrm{a}}$} \\
\hline \multirow{3}{*}{$\frac{\text { Model }}{\text { (Constant) }}$} & $\begin{array}{l}\text { Unstanc } \\
\text { Coeffi }\end{array}$ & $\begin{array}{l}\text { ardized } \\
\text { ients }\end{array}$ & $\begin{array}{l}\text { Standardized } \\
\text { Coefficients }\end{array}$ & \multirow[b]{2}{*}{$\mathrm{t}$} & \multirow[b]{2}{*}{ Sig. } \\
\hline & $\mathrm{B}$ & Std. Error & Beta & & \\
\hline & ,681 & 6,629 & &, 103 & ,922 \\
\hline $\begin{array}{l}\text { Kepemimpinan } \\
\text { Kepala Sekolah }\end{array}$ & ,934 & ,211 & ,875 & 4,435 & ,004 \\
\hline
\end{tabular}

a. Dependent Variable: Kinerja Guru

Berdasarkan tabel di atas dapat diperoleh persamaan linear regresi sebagai berikut:

$$
\begin{aligned}
& \mathrm{Y}=\mathrm{A}+\mathrm{B} \mathrm{X} \\
& \mathrm{Y}=0,681+0,934 \mathrm{X}
\end{aligned}
$$

Hasil analisis dari persamaan diatas sebagai berikut:

1) Konstanta sebesar 0,681

2) Koefisien kepemimpinan kepala sekolah sebesar 0,934. Koefisien yang bernilai positif berarti artinya terjadi hubungan positif antara kepemimpinan kepala sekolah terhadap kinerja guru di SDN 45 Lempangan Sinjai Selatan.

Dari tabel diatas dapat dijelaskan bhawa variabel kepemimpinan kepala sekolah memiliki hubungan yang signifikan dan memiliki nilai positif. Dari kedua analisis tersebut dapat diartikan bahwa koefisien arah regresi antara variable kepemimpinan kepala sekolah menyatakan adanya pengaruh positif terhadap kinerja guru. Variabel kepemimpinan kepala sekolah (X) mempunyai pengaruh positif terhadap kinerja guru $(\mathrm{Y})$, dengan nilai koefisien regresi sebesar 0,934.

Hal ini menunjukkan bahwa koefisien regresi antara variabel kepemimpinan kepala sekolah sejalan dengan kinerja guru di SDN 45 Lempangan Sinjai Selatan.

d. Uji Koefisien Determinasi

Berdasarkan hasil penelitian yang telah diolah dengan menggnuakan software SPSS 25, maka didapatkan hasil sebagai berikut:

\begin{tabular}{|c|c|c|c|c|}
\hline \multicolumn{5}{|c|}{ Model Summary } \\
\hline Model & $\mathrm{R}$ & R Square & $\begin{array}{l}\text { Adjusted R } \\
\text { Square }\end{array}$ & $\begin{array}{l}\text { Std. Error of the } \\
\text { Estimate }\end{array}$ \\
\hline 1 &, $875^{\mathrm{a}}$ & ,766 & ,727 & 1,396 \\
\hline
\end{tabular}

Tabel 6

a. Predictors: (Constant), Kepemimpinan Kepala Sekolah

b. Dependent Variable: Kinerja Guru

Tabel diatas menunjukkan bahwa nilai koefisien determinasi $\mathrm{R}=0,875$, $\mathrm{R}$ Square adalah 0,766 dan koefisien determinasi yang telah disesuaikan (Adjusted $R$ Square) sebesar 0,727 artinya bahwa kepemimpinan kepala sekolah berpengaruh terhadap kinerja guru sebesar $76,6 \%$. Sedangkan sisanya sebesar $23,4 \%$ dengan kata lain terdapat aspek-aspek selebihnya yang memiliki pengaruh terhadap kepemimpinan kepala sekolah di SDN 45 Lempangan Sinjai Selatan. 


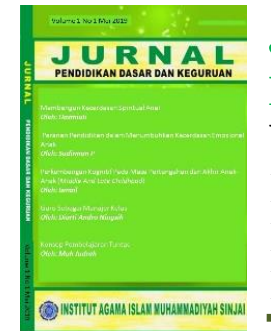

JURNAL

Pendidikan Dasar dan Keguruan

Volume 6, No. 1, 2021

ISSN (print) : 2527-578X

ISSN (Online): 2715-6818

Homepage : http://journal.iaimsinjai.ac.id/index.php/JPDK

e. Annova

Tabel 7

\begin{tabular}{|c|c|c|c|c|c|c|}
\hline \multicolumn{7}{|c|}{ ANOVA $^{a}$} \\
\hline \multicolumn{2}{|c|}{ Model } & $\begin{array}{l}\text { Sum of } \\
\text { Squares }\end{array}$ & Df & Mean Square & $\mathrm{F}$ & Sig. \\
\hline 1 & Regression & 38,313 & 1 & 38,313 & 19,670 &, $004^{\mathrm{b}}$ \\
\hline & Residual & 11,687 & 6 & 1,948 & & \\
\hline & Total & 50,000 & 7 & & & \\
\hline
\end{tabular}

a. Dependent Variable: Kinerja Guru

b. Predictors: (Constant), Kepemimpinan Kepala Sekolah

Sumber Data: Hasil Output SPSS 25

Dari tabel diatas dapat diketahui nilai Fhitung= 19,670 dan F tabel= 5,99. Fhitung=19,670 >

Ftabel $=5,99$, maka $\mathrm{H}_{0}$ ditolak dan $\mathrm{H}_{1}$ diterima. Artinya terdapat pengaruh kepemimpinan kepala sekolah terhadap kinerja guru di SDN 45 Lempangan Sinjai Selatan.

Tabel 8

\section{Coefficients $^{\mathrm{a}}$}

\begin{tabular}{|c|c|c|c|c|c|}
\hline \multirow[b]{2}{*}{ Model } & \multicolumn{2}{|c|}{$\begin{array}{c}\text { Unstandardized } \\
\text { Coefficients }\end{array}$} & \multirow{2}{*}{$\begin{array}{c}\text { Standardized } \\
\text { Coefficients } \\
\text { Beta } \\
\end{array}$} & \multirow[b]{2}{*}{$\mathrm{t}$} & \multirow[b]{2}{*}{ Sig. } \\
\hline & $\mathrm{B}$ & Std. Error & & & \\
\hline 1 (Constant) & ,681 & 6,629 & & , 103 & ,922 \\
\hline $\begin{array}{l}\text { Kepemimpinan } \\
\text { Kepala Sekolah }\end{array}$ & ,934 &, 211 & 875 & 4,435 & ,004 \\
\hline a. Dependent Variab & rja Guru & & & & \\
\hline
\end{tabular}

Sumber Data: Hasil Output SPSS 25

Pada tabel di atas juga dapat ditentukan nilai t-hitung. Dihitung pada pengaruh kepemimpinan kepala sekolah terhadap kinerja guru adalah thitung adalah 4,435 dan t-tabel adalah 2,477. Jika thitung 4,435 > dari ttabel 2,477 maka $\mathrm{H}_{0}$ ditolak, $\mathrm{H}_{1}$ diterima artinya Terdapat pengaruh kepemimpinan kepala sekolah terhadap kinerja guru di SDN 45 Lempangan Sinjai Selatan.

Dari uraian yang telah dikemukakan pada hasil penelitian di atas terlihat bahwa kepemimpinan kepala sekolah memiliki pengaruh terhadap kinerja guru di SDN 45 Lempangan Sinjai Selatan. Adapun besar pengaruh kepemimpinan kepala sekolah dapat dilihat pada tabel coefficients sebesar 0,934 atau 93,4\% dengan kata lain terdapat aspek-aspek selebihnya yang memiliki pengaruh terhadap kinerja guru di SDN 45 Lempangan Sinjai Selatan.

\subsection{Pembahasan}

Terdapat pengaruh kepemimpinan kepala sekolah terhadap kinerja guru di SDN 45 Lempangan Sinjai Selatan. Berdasarkan hasil analisis regresi sederhana yang telah dilakukan melalui 
Volume 6, No. 1, 2021

ISSN (print) : 2527-578X

ISSN (Online): 2715-6818

Homepage : http://journal.iaimsinjai.ac.id/index.php/JPDK

program SPSS 25, diperoleh hasil bahwa dari 8 responden yang ada di SDN 45 Lempangan Sinjai Selatan. Pada tabel coefficients diketahui thitung kepemimpinan kepala sekolah 4,435 > 2,477 ttabel jadi $\mathrm{H}_{0}$ ditolak dan $\mathrm{H}_{1}$ diterima, maka dapat disimpulkan bahwa kepemimpinan kepala sekolah secara signifikan berpengaruh terhadap kinerja guru di SDN 45 Lempangan Sinjai Selatan. Sedangkan pada nilai probablitas $0,004<0,05$, maka kepemimpinan kepala sekolah memiliki pengaruh terhadap kinerja guru di SDN 45 Lempangan Sinjai Selatan.

Untuk mengetahui besar pengaruh antara kepemimpinan kepala sekolah terhadap kinerja guru dapat dilihat pada tabel model summary dengan melihat R Square $=0,766$ atau 76,6 \% jadi besar kepemimpinan kepala sekolah terhadap kinerja guru adalah 76,6 \% dengan kata lain terdapat aspekaspek selebihnya yang memiliki pengaruh terhadap kinerja guru di SDN 45 Lempangan Sinjai Selatan.

Dari kedua pengujian hipotesis tersebut bahwa antara kepemimpinan kepala sekolah terhadap kinerja guru. Dalam hal ini telah dibuktikan dengan melakukan penelitian di SDN 45 Lempangan Sinjai Selatan, sehingga hasil penelitian tersebut dapat disimpulkan bahwa antara kepemimpinan kepala sekolah memiliki pengaruh positif dan signifikan dengan kinerja guru di SDN 45 Lempangan Sinjai Selatan.

\section{Kesimpulan}

Dari hasil penelitian tentang pengaruh kepemimpinan kepala sekolah terhadap kinerja guru di SDN 45 Lempangan Sinjai Selatan, penulis menghasilkan kesimpulan yaitu: Kepemimpinan kepala sekolah memiliki pengaruh positif dan signifikan terhadap kinerja guru di SDN 45 Lempangan Sinjai Selatan. Hal ini diperoleh berdasarkan hasil analisis dengan menggunakan SPSS 25, Pada tabel coefficients diketahui thitung kepemimpinan kepala sekolah 4,435>2,477 ttabel dan nilai probablitas $0,004<0,05$ dan pada tabel model summary dengan melihat $\mathrm{R}$ Square $=0,766$ atau 76,6 \% . Besar pengaruh kepemimpinan kepala sekolah terhadap kinerja guru di SDN 45 Lempangan Sinjai Selatan adalah $76,6 \%$.

\section{Ucapan Terimakasih}

Puji syukur penulis panjatkan kepada Allah SWT yang telah memberikan rahmat serta karunia, sehingga penulis akhirnya dapat menyelesaikan jurnal ini. Penulis menyadari bahwa tanpa adanya bantuan dan dorongan dari berbagai pihak, penyelesaian jurnal ini tidak akan terwujud. Oleh karena itu, dengan ketulusan dan kerendahan hati, penulis mengucapkan terimakasih kepada semuab pihak yang membantu dalam proses penyelesaiannya. Terimakasih atas waktu serta masukan yang sangat bermanfaat. 
Barnawi dan Mohammad Arifin, (2012) Kinerja Guru Profesional Instrumen Pembinaan, Peningkatan dan Penilaian, Jogjakarta: Ar-Ruz Media

E. Mulyasa, (2013) Menjadi Kepala Sekolah Proesional dalam Konteks Menyukseskan MBS dan $K B K$, Bandung: PT Remaja Rosdakarya

Harsidar. A, (2016) "Pengaruh Game Playstation 2 Smack Down Terhadap Karakter Peserta Didik SDN No. 05 Sinjai Utara", Skripsi Sarjana, (Sinjai: IAIM Sinjai)

Herawati Syamsul, (2017) "Penerapan Kepemimpinan Kepala Sekolah dalam Meningkatkan Kinerja Guru Pada Jenjang Sekolah Menengah Pertama (SMP)", e-journal Idaarah, Vol. I Nomor II

Kompri, Manajmen Pendidikan Komponen-Komponen Elementer Kemajuan Sekolah, Cet. II; Yogyakarta: Ar-Ruzz Media, 2016

Sugiyono, (2011) Metode Penelitian Kuantitatif, Kualitatif dan R\&D. Bandung: Afabeta

Sugiyono, (2017) Metode Penelitian dan Pengembangan Research and Development, Cet. III; Bandung: Alfabeta

Supardi, Kinerja Guru, (2014) Cet. II; Jakarta: Rajawali Pers

Undang-Undang RI Nomor 14 Tahun 2005 tentang Guru dan Dosen. (2006) Cet I; Yogyakarta: Pustaka Yustisia

Wahyuningsih, (2018) "Kepemimpinan Kepala Sekolah dalam Meningkatkan Kinerja Guru Di SMK Muhammadiyah 02 Bandar Lampung", Skripsi, Universitas Islam Negeri Raden Intan Lampung Fakultas Tarbiyah dan Keguruan, 1439 H/2018 M. 